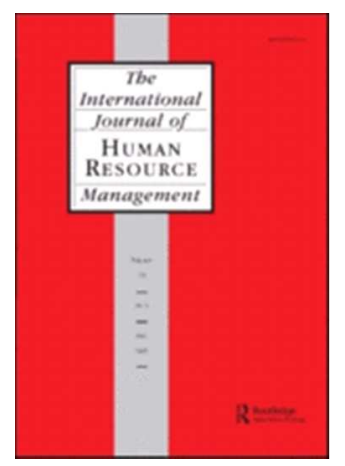

\title{
Understanding Skilled Migrants' Qualification-Matched Employment in the Host Country: A Multidisciplinary Review and a Conceptual Model
}

\begin{tabular}{|r|l|}
\hline Journal: & The International Journal of Human Resource Management \\
\hline Manuscript ID & RIJH-2017-0761.R1 \\
\hline Manuscript Type: & Special Issue Paper \\
\hline Keywords: & Employment, Skilled migration, Labor market, Destination, Job \\
\hline \multicolumn{2}{|l}{} \\
\hline
\end{tabular}

\section{SCHOLARONE"}

Manuscripts 


\title{
Understanding Skilled Migrants' Qualification-Matched Employment in the Host Country: A Multidisciplinary Review and a Conceptual Model
}

\begin{abstract}
Globalization has led to an increase in international mobility in many occupational fields. Therefore, scholars from a variety of disciplines have studied the topic of skilled migration. The purpose of this study is to review and synthesize the empirical research on skilled migrants' qualification-matched employment across multiple disciplines. Skilled migrants are people on the move who possess university degrees or extensive work experience in professional fields when they leave their countries of origin to seek employment elsewhere. This review synthesizes findings of 106 empirical studies published from 1990 to mid-2017 on skilled migrants' employment. We develop a conceptual model that includes antecedent conditions associated with skilled migrant qualification-matched employment in their host country and its outcomes. We also highlight the role of multi-level factors and moderating variables associated with skilled migrants' possibility of obtaining qualification-matched employment. Our review has implications for human resource scholars and practitioners concerned with skilled migrants' employment and labor market.
\end{abstract}

Keywords: Skilled migration; employment; labor market; destination; job

\section{Introduction}

Abigale, an experienced nurse, moved from the Philippines to Australia through a General Skilled Migration visa application process with hopes for a better life and the opportunity to work in a developed country. Within the first year of her arrival in Australia, she applied for hundreds of jobs but received no offers. Born, raised, and trained in the Philippines, Abigale felt she was at a disadvantage compared to the local graduates with whom she had to compete in the job market. In Australia, Abigale didn't have a support network, and her extensive work experience, which would have been well received in her home country, seemed irrelevant to Australian employers. This review focuses on skilled migrants with concerns like Abigale's. 
Skilled migrants are defined as people on the move who possess university degrees or extensive work experience in a professional field at the time they leave their countries of origin to seek employment elsewhere (Crowley-Henry, O’Connor, \& $\mathrm{Al}$ Ariss, 2016). Governments close their skill gaps by attracting skilled migrants through various programs granting entry and work permissions to qualified individuals from other countries (Wright, 2014). Moreover, difficult political and economic situations such as war, insecurity, and unemployment (Cerdin, Diné, \& Brewster, 2014) prompt the skilled and educated to leave their home countries for the developed world, with high hopes for improved lifestyles and work/educational opportunities for themselves and their families (van Riemsdijk, 2013; Zikic, Bonache, \& Cerdin, 2010).

Research has established the economic contributions skilled migrants provide to their host country (OECD, 2014). Skilled migrants with superior levels of education and work experience can fill industry demands for a skilled labor force, boost economic growth, and improve native born populations' earnings (Kangasniemi, Winters, \& Commander, 2007; Oreopoulos, 2011). Highly skilled migrants create businesses in the mainstream of their new country's economy that equal or exceed the economic performance of their native counterparts, while low-skilled migrants create small, often unstable and less profitable businesses (Szarucki, Brzozowski, \& Stankeviciene, 2016). Furthermore, highly skilled migrants "produce localized knowledge spillovers, positive externalities, and significant local multipliers generating additional boosts in regional economic vitality" (Wright, Ellis, \& Townley, 2017, p. 186). Host countries can benefit from these economic advantages if skilled migrants fill jobs matching their skill levels (Wright et al., 2017). In fact, employment has been found as "the single biggest determinant of migrants' net fiscal contribution" (OECD, 2014, p. 3). 
Paradoxically, although skilled immigrants are meant to bridge their host countries' skill gaps, obtaining jobs in their host country commensurate with their qualifications is their most significant challenge (Bauder, 2003; OECD, 2014; Syed, 2008). Despite their contributions, skilled migrants' pathways to skilled employment are seldom smooth; they often must overcome numerous obstacles (Syed, 2008). Due to the multitude of challenges, obtaining employment matching their qualifications is a core theme of skilled migrants who secure continued employment and carve out normatively successful careers (Al Ariss et al., 2012). This paradox calls for an in-depth review and analysis of skilled migrant qualificationmatched employment literature, which is the objective of this review.

Since the late 1980s, international skill mobility has become a topic of academic inquiry. Globalization has led to the emergence of international mobility in many professions such as healthcare, academia, science, and engineering (Cantwell \& Taylor, 2013). Also, globalized businesses have created the need for global talent, and governments have facilitated movement across borders to increase the inflow of skilled labor (Al Ariss, Makela, \& De Cieri, 2015). Since international talent flow has impacted many occupational fields, scholars from a variety of disciplines have examined this topic from multiple perspectives (e.g., Groutsis \& Arnold, 2012; Reid, 2012). For example, sociologists have been concerned with social structures influencing migrant integration into their host country context (e.g., Munoz-Comet, 2016), economists have attended migrants' labor market participation and employment outcomes (e.g., Riano, 2011), geographers and demographers have examined the geography of the skilled migrants' mobility and their demographic characteristics (e.g., Liu \& Xu, 2017; Strauss \& McGrath, 2017), and management scholars have been concerned with careers of skilled migrants as well as issues related to managing migrant workers (e.g., Guo \& Al Ariss, 2015; Zikic, 2015). Insights gained by these disciplines have yet to be merged to provide a holistic picture of skilled migrant employment. 
The most recent reviews on the topic of skilled migrants published in management journals (Al Ariss \& Crowley-Henry, 2013; Crowley-Henry et al., 2016) broadly focused on migrants' careers and did not specifically address whether or not such employment paths matched skilled migrants' qualifications. Al Ariss and Crowley-Henry (2013) critically reviewed the management literature on self-initiated expatriation and migration. The authors compared profiles of self-initiated expatriates and skilled migrants and showed that the literature has conceptualized skilled migrants as ethnic minorities from developing countries and self-initiated expatriates as selected from the most privileged individuals from developed countries. Crowley-Henry et al.'s (2016) systematic review synthesized recent studies (including only publications since 2000) on skilled migrants' careers published in business and management journals. The authors searched for career and migration or skilled migrant keywords; the 47 included articles were concerned with "the workplace careers of this population, or the workplace experiences of this population which would have an impact on their careers" (p. 3). Our review complements that of Crowley-Henry et al. (2016) by focusing on the factors associated with skilled migrants' employment that match their qualifications and pave the way for future quantitative studies on the topic.

In this review, we synthesize findings of empirical research focusing on skilled migrants' qualification-matched employment. Our synthesis will be presented in the form of a conceptual model that answers the following questions: (i) What are the antecedent conditions that contribute to qualification-matched employment of skilled migrants in their host country?; (ii) How does skilled migrants' qualification-matched employment link to their well-being and employment outcomes?; (iv) How does the host country's context help skilled migrants find employment that matches their qualifications?; and (v) What variables moderate the relationship between antecedent conditions and skilled migrants' qualificationmatched employment? 
Our review provides four major contributions. First, it integrates the literature on skilled migrants in multiple disciplines to shed light on the factors that enable them to find employment aligned with their qualifications; therefore, our review highlights the multidisciplinary nature of the skilled migrants' employment and deepens our understanding of it as a societal phenomenon. Second, our review proposes a conceptual model that contributes to theory building by providing a comprehensive picture of skilled migration phenomena. It also contributes to human resource management (HRM) scholarship about skilled migrants as it paves the way for future quantitative research by suggesting antecedents, outcomes, and contextual and intervening variables worthy of investigation. Finally, this review identifies gaps in the extant literature and suggests avenues for future research.

\section{Methods}

"Skilled migrants" have been labeled differently across studies due to a lack of consensus over the definition of this population of workers (Bruland \& Rusten, 2012; Crowley-Henry et al., 2016). Informed by systematic literature review methodology (Higgins \& Green, 2011), we used the following comprehensive list of keywords and searched the Web of Science database and the Social Sciences Citation Index: "Skilled migrant*" or "Skilled migration" or "Skilled immigrant*" or "Skilled Temporary Migrant*” or "International migrant*" or "Qualified immigrant*" or "Skilled Migrant worker*" or "Professional immigrant*" or "Highly-skilled migrant*" or "Highly skilled workers migra*" or "High-skilled migrant*" or "Skilled mobility" or "professional mobility" or "Immigrant job seeker*" or "Skilled ethnic minor*" or "Foreign S\&E" or "high-skilled women" or "Educated migrant" or "Overseas trained" or "Foreign-Born" or "Ethnic-Minority Professional*" or "Highly-Skilled Lab?r" or "Brain drain" or "Brain gain" or "Brain Circulation" or "Brain Waste" combined with “employment," "work," “career," “job,” and "recruitment”. 
We added the search criteria of English language, articles as document type, and timeline between 1990 and 2017. We included articles after 1990 because that is the year that many countries amended their immigration policies to facilitate the entry of skilled foreign workers ${ }^{1}$. Due to the multidisciplinary focus of this review, we refined the search to include the following Web of Science Categories: Management, Business, Industrial Relations Labor, Public Administration, Psychology Applied, Psychology Social, Sociology, Economics, Social Sciences Interdisciplinary, Education Educational Research, Public Environmental, Occupational Health, Demography, and Geography. Our search retrieved 826 articles, which were exported to RefWorks for further screening.

We read the titles and abstracts of all the publications and screened them according to three questions: (1) Does the article report an empirical study (not conceptual/review)?; (2) Is the sample selected from international skilled migrants (not low-skilled migrants or organization-sponsored expatriates or internal migrants?); (3) Does the article focus on the skilled migrants' employment/job/work in the host country? Articles that did not meet one or more of the three inclusion criteria were excluded from the review. For example, studies that focused on migration decisions and intention to return were excluded. A total of 106 articles were selected for further analysis. Table 1 presents the list of the journals and article frequency.

After inserting the selected articles into NVivo software, we used the constant comparative analysis method (Lincoln \& Guba, 1985) to analyze findings that focused on the skilled migrants' qualification-matched or qualification-unmatched employment. We applied open coding, read the findings of articles line by line, and then coded findings related to employment with conceptual labels. The emerging concepts were classified and grouped into

\footnotetext{
${ }^{1}$. Since 1990 , the number of international migrants increased by $65 \%$ ( 53 million) in the global North, and by $34 \%$ ( 24 million) in the global South (UN-DESA) (OECD, 2013)
} 
categories. The categories were constantly compared during the analysis process (Birks \& Mills, 2011). Finally, we examined the connections between categories and organized them into a model (Strauss \& Corbin, 1990; see Figure 1).

\section{Findings}

\section{Overview of Reviewed Studies}

The 106 papers we reviewed were published in 81 journals with Management (17), Demography (17), Economics (16), Geography (14), and Sociology (10) disciplines housing the highest number of publications on skilled migrant employment. Journals in other disciplines, including Public Environmental Occupational Health (9), Psychology and Applied Psychology (7), Industrial Labor Relations (7), Educational Research (6), and Public Administration (3), published fewer studies on the topic. Our review revealed that the number of qualitative studies on the topic (50 studies) was almost equal to the quantitative ones (49 studies), with seven studies adopting a mixed-method approach. Skilled migrants employment was mainly studied in Australia and New Zealand (23 studies), the United States (22 studies), The UK and Ireland (13 studies), other western European countries (18 studies), and Canada (12 studies). The remaining studies focused on skilled migrants' employment in Asia (5 studies), more than one host country (8 studies), and multiple unspecified host countries (5 studies). Publications on skilled migrants increased significantly after 1990 with only five publications by the end of 2000, 26 publications from 2001 to 2010 , and seventyfive publications between 2011 and mid-2017. Below, we provide a conceptual model that integrates and organizes the results from the studies included in the review (Figure 1).

Insert Figure 1 about here 


\section{A Conceptual Model of Skilled Migrants' Qualification-Matched Employment \\ Qualification-matched employment}

Our analysis suggested that skilled migrant employment as reflected in the literature can be categorised in two modes that are the two sides of one coin: qualification-matched or qualification-unmatched employment. A skilled migrant will be in a qualification-matched status if their skills and field of training (professional background) match the requirements of the job she/he obtains in the host country (Banerjee \& Mai, 2014; Dell'Aringa \& Pagani, 2011). On the other hand, a skilled migrant in a qualification-unmatched status may have accepted jobs outside of and below their skills and irrelevant to their training (McDonald \& Valenzuela, 2017). Therefore, we refer to qualification-matched employment as a variable that summarizes how employment has been conceptualized in the extant literature.

We coded each reviewed study for the variables associated with skilled migrants' qualification-matched or qualification-unmatched employment. We synthesized and organized our findings in a model that includes the antecedents and outcomes of skilled migrants' qualification-matched employment in the host country. Informed by Syed's (2008) relational framework, our model acknowledges that multi-level factors link to skilled migrants' qualification-matched employment. The relational framework (Syed, 2008) discusses factors at micro-, meso-, and macro- levels contributing to skilled migrants' employment prospects. Our review organizes the factors associated with skilled migrants' qualification-matched employment into individual-, organizational-, host country national-, and international- level factors. Our model synthesizes research findings regarding the association of qualification-matched employment with individual level outcomes, and illustrates factors that function as moderators of the relationships among qualificationmatched employment, its antecedents, and its outcomes. Since the factors emerged through a synthesis of the findings, one study may have contributed to more than one factor. Therefore, 
the frequencies presented in the text below refer to the number of studies that included each specific factor in their findings and therefore do not add up to 106, which is the total number of studies included in the review.

\section{Antecedents of qualification-matched employment: Individual-level factors}

Host country language proficiency. Thirty studies referred to the importance of language proficiency in their findings regarding skilled migrants' employment in the host country. Quantitative studies examined the contributions of language proficiency by using self-report measures of language proficiency such as the single-item good or poor language skills scale (e.g., Miller \& Neo, 1997; Oreopoulos, 2011) or pre-existing data in which they used proxies such as mother tongue, non-native speaker status, or citizenship as indicators of host country language ability (e.g., Beckhusen et al., 2013; Reid, 2012). Qualitative studies suggested that migrants found a lack of language proficiency to act as a barrier in obtaining qualification-matched employment (e.g., Mulholland \& Ryan, 2014; Winterheller \& Hirt, 2017). Synthesis of the quantitative and qualitative findings suggested that skilled migrants with lower host country language proficiency are less likely to obtain qualification-matched employment in the host country (e.g., Beckhusen, Florax, Poot, Waldorf, 2013; Fossland, 2013; Winterheller \& Hirt, 2017).

Host country educational credentials. The extant literature defines skilled migrants as those possessing tertiary educational credentials - at least a bachelor's degree - at the time of arriving at the host country (e.g., Crowley-Henry et al., 2016). Thirty-one studies included education-related factors such as educational level (e.g., Bazillier \& Boboc, 2016) and area of qualification (e.g., Thondhlana, Madziva, \& McGrath, 2016), with 28 of those studies suggesting that having host country educational credentials is the most impactful factor in obtaining qualification-matched employment (e.g., Oreopoulos, 2011; Owusu \& Sweetman, 2015). Skilled migrants who obtained their credentials from universities located in countries 
foreign to the host country (at their home country or another country) had lower chances of obtaining qualification-matched employment compared to those who graduated from host country institutions (e.g., Hawthorne, 2010; Fossland, 2013). Other studies suggested that skilled migrants chose to develop new credentials or re-train in the host country in order to compete with host country graduates (e.g., Banerjee \& Mai, 2014; Zikic et al., 2010).

Professional network in host country. Thirty-one studies examined how factors related to social networks - often referred to as social capital— were associated with skilled migrants' employment in the host country. Social networks studied in the literature comprised non-migrants as well as migrant connections (Aure, 2013), co-ethnics, kin, family members (Thondhlana et al., 2016), friends and personal contacts (Cooke et al., 2013; Trlin, 2012), and professional connections (Hawthorne, 1997; Reid, 2012). Among different types of social networks, professional connections residing in the host country were most effective in enabling skilled migrants to secure qualification-matched employment, especially during early stages of settlement in the host country (e.g., Cooke et al., 2013; Shinozaki, 2014; Thondhlana et al., 2016). Interestingly, studies suggested that when skilled migrants' connections were limited to co-ethnics and family members- - without also having workrelated interactions - the migrants' chances of obtaining qualification-matched employment decreased (e.g., Vidal-Coso \& Miret-Gamundi, 2014; Winterheller \& Hirt, 2017).

Host country work experience. Twenty-nine studies elaborated on the effects of work experience on skilled migrants' employment in their host country. We observed a dominant pattern across findings of qualitative and quantitative findings: a lack of host country work experience decreased the possibility of obtaining qualification-matched employment in the host county among skilled migrants (e.g., Liversage, 2009; Thondhlana et al., 2016). The reviewed studies argued that employers' inability to recognize skilled migrants' home country work experience explains the negative association of the lack of 
local work experience and qualification-matched employment (e.g., Green, Kler, \& Leeves, 2007; Mahmud et al., 2014). However, other studies reported that skilled migrants who obtain discipline-specific work experience, such as internships, have a higher chance of obtaining qualification-matched employment (e.g., Blackmore, Gribble, \& Rahimi, 2017; Trlin, 2012).

Host country cultural knowledge. Familiarity with host country culture was examined in 27 studies (e.g., Blackmore et al., 2017). The majority of studies reflected cross cultural issues faced by skilled migrants in the host country and showed that a lack of cultural understanding could function as a barrier to qualification-matched employment (e.g., Guerrero \& Rothstein, 2012; Kim, Hogge, Mok, \& Nishida, 2014). In cases where skilled migrants sought employment in businesses that primarily served local markets, evidence of host country knowledge proved to be critical (e.g., Aure, 2013; Fossland, 2013). While the majority of studies suggested that skilled migrants find it hard to use their generic and workspecific cultural knowledge gained in their home countries, three studies showed that home country cultural knowledge created qualification-matched employment opportunities. For example, cultural knowledge created opportunities in non-English speaking countries for language teachers from English-speaking countries (e.g., Farrer, 2014; Tzeng, 2010; Van Laer \& Janssens, 2017).

Antecedents of qualification-matched employment: Organizational-level factors

Employer's equality and diversity policy implementation. Findings of 46 studies referred to different aspects of employment equality and diversity policy implementations that were associated with skilled migrants' employment. Qualitative studies that conducted interviews with skilled migrants or interviews with recruitment agencies revealed that skilled migrants experienced recruitment and selection discrimination (e.g., Al Ariss, Vassilopoulou, Oezbilgin, \& Game, 2013; Blackmore et al., 2017; DelCampo, Jacobson, Van Buren, \& 
Blancero, 2011; Fossland, 2013). According to the reviewed studies, skilled migrants' experiences of discrimination stemmed from their employer's perceptions and biases (e.g., Hawthorne, 1997; Horverak; Sandal; Bye; Pallesen, 2013; Trlin, 2012). The dominant pattern across studies suggests that employer's selection biases against particular countries of origin decreased skilled migrants' access to qualification-matched employment. For example, employers' negative perceptions hindered qualification-matched employment among skilled migrants from developing countries such as Central and Eastern Europe (e.g., Felker, 2012), the Middle East (e.g., Oreopoulos, 2011), Latin America and the Caribbean (e.g., Gandini \& Lozano-Ascencio, 2016), and the Former Soviet Union (e.g., Weiss, Sauer, \& Gotlibovski, 2003). On the other hand, employers' positive perceptions helped skilled migrants from developed/western countries to obtain qualification-matched employment (e.g., Green, Kler, \& Leeves, 2007; Tzeng, 2010).

Antecedents of qualification-matched employment: Host country national-level factors

Visa and work authorization. Forty-six studies included variables related to skilled migrants' visa configurations and work authorization (e.g., Axelsson, 2017; Kler, 2006; Varma, 2010). Among all the visa-related factors, work authorization - a visa configuration constraining or facilitating access to work — was most associated with skilled migrants' access to qualification-matched employment, employment mobility, and even professional development and salary negotiations (e.g., Boese et al., 2013; Kim, Hogge, Mok, \& Nishida, 2014). Studies showed that during their stay in the host country, skilled migrants attempted to switch to visa statuses that facilitated their pathways to qualification-matched employment (e.g., Thondhlana et al., 2016). Studies described temporary migrant workers - defined as "persons who live in a host country without a right of long-term residence and who undertake paid work during their stay" (Boese et al., 2013, p. 321) — as the most vulnerable in regard to gaining access to qualification-matched employment (e.g., Luthra, 2009; Velayutham, 2013). 


\begin{abstract}
A similar pattern of disadvantage due to their visa situation was observed among females who accompanied their spouses. Most found themselves deskilled and re-domesticated (e.g., Cooke et al., 2013; Yeoh \& Willis, 2005), with little access to qualification-matched employment (Shinozaki, 2014).
\end{abstract}

Professional qualification recognition. Thirty-two studies discussed the importance of being authorized and obtaining a host country license in finding qualification-matched employment (e.g., Girard \& Bauder, 2007; Peterson, Pandya, \& Leblang, 2014). A noticeable pattern observed across studies was that rigid credential valuation through professional bodies or licensing agencies divided occupational fields into regulated and unregulated. For example, studies focusing on health-related fields showed that rigid professional licensing hindered migrant nurses and doctors from practicing in their areas of specialty or qualification-matched employment (e.g., Fossland, 2013; Hawthorne, 1997). On the other hand, other studies found that skilled migrants with qualifications in less regulated fields experience less downgrading in their occupational status upon migration (e.g., Banerjee \& Mai, 2014; Thondhlana et al., 2016).

Skilled labor demand. Findings of the reviewed studies showed that skilled migrants were more likely to obtain qualification-matched employment in labor market sectors with a limited native workforce labor supply (e.g., the geriatric specialty; Bornat, Henry, \& Raghuram, 2011; Cantwell \& Taylor, 2013; Francis, Chapman, Doolan, Sellick, \& Barnett, 2008; Weller, 2017). Studies suggested that governments, industry sectors, and employers experiencing high demands for specific skills often had less rigid entry requirements (Harris, 2014), offered fast-track pathways to employment (Groutsis \& Arnold, 2012), sourced visa sponsorship (Bahn, 2014), and directly recruited from abroad (van Riemsdijk, 2013). Across studies it was evident that skilled migrants had a better chance of finding qualification- 
matched employment in "a designated area of need" in the host country (Groutsis \& Arnold, 2012, p. 337).

Host country government integration initiatives. Only 6 studies focused on governments' integration initiatives and reported effects of such initiatives on skilled migrants' qualification-matched employment. These studies found that participating in training programs offered by governments helped skilled migrants obtain qualificationmatched employment (e.g., Myles, Cheng, \& Wang, 2006). For example, the Leonardo program in Finland and Gippsland Inspiring Professional Standards among International Experts (GIPSIE) in Australia were designed to provide educational support and learning resources to newly arrived physician immigrants (Hardill \& MacDonald, 2000; Wright et al., 2012). Other studies in this category reported that skilled migrants noticed a short supply of integration initiatives such as high-quality language courses to help migrants overcome barriers to qualification-matched employment in the host country (Kuusio et al., 2014).

Host country economic stability. Six studies examined how host country economic stability was linked to skilled migrants' qualification-matched employment (e.g., Cantwell \& Taylor, 2013; Farrer, 2014; Vargas-Silva, 2016). One conclusion based on the reviewed studies is that during instable economic situations, skilled migrants increasingly accept jobs that are below their qualification levels (Gandini and Lozano-Ascencio, 2016; Kler, 2006). Antecedents of qualification-matched employment: International-level factors

Political relationships between home and host country. Four studies reported effects of international-level factors on skilled migrants' qualification-matched employment in the host country (Batnitzky \& McDowell, 2011; Cantwell \& Taylor, 2013; Hawthorne, 2010; van Riemsdijk, 2013). The pattern emerging from the existing findings suggests that political relationships between countries can be associated with skilled migrants' qualification-matched employment. For instance, the Second World War created labor 
deficits in certain countries and led to the recruitment of migrant workers in needed professional fields (Batnitzky \& McDowell, 2011). Similarly, accession to the European Union in 2004 led to an increased westward migration of citizens from the new-memberstates (van Riemsdijk, 2013). In contrast, terrorist attacks (e.g., September 11) led to several periods of restricted access to western labor markets and significantly changed the public view of immigrants (Hawthorne, 2010).

\section{Moderators of the relationships between qualification-matched employment and its antecedents}

Gender. Eighteen studies examined the role of gender in skilled migrants' employment in the host country. Findings of these studies suggest one overarching pattern: gender moderates the relationship between antecedents and qualification-matched employment such that women migrants were less likely to access qualification-matched employment (e.g., Aure, 2013; Riano, 2011). This pattern was most significant among women migrants entering the host country as dependents (e.g., Cooke et al., 2013; Fossland, 2013). Reviewed studies showed that women migrants' under-representation in high-demand occupations such as business administration, engineering, and IT and their presence in education, health, and culture-related professions partially accounted for their disadvantaged position in the labor market (Gandini \& Lozano-Ascencio, 2016). A small proportion of skilled migrant females entered highly-paid jobs that matched their qualifications (Gandini \& Lozano-Ascencio, 2016; Kler, 2006).

Individual agency. Thirteen studies referred to skilled migrants' agency as a factor that helped them overcome barriers they faced in accessing qualification-matched employment. Individual agency was defined as the "power and influence to affect changes in their lives and work as permitted and legitimated by their position in webs of social and economic relations" (Al Ariss, Vassilopoulou, Oezbilgin, \& Game, 2013, p. 1236). Studies examining the individual agency factor suggested that skilled migrants exercised their agency 
to pursue education in the host country (e.g., Liversage, 200; Thondhlana et al., 2016), to practice the host country's language and extend their social networks as ways to leverage their access to qualification-matched employment (Das Gupta et al., 2014; Winterheller \& Hirt, 2017; Zikic et al., 2010), or to persist relentlessly in job-hunting until they re-secured qualification- matched employment (Das Gupta et al., 2014; Harris, 2014). Other studies showed that skilled migrants exercised their agency by rejecting jobs that did not match their qualifications or by withdrawing from the labor market and leaving the host country (Al Ariss et al., 2013; Liversage, 2009; Riano, 2011; Van Laer \& Janssens, 2017).

Length of residence in host country. Seven studies examined length of residence in a host country in their analysis of skilled migrants' employment. Findings of these studies suggest that over time, skilled migrants experienced improvements in their occupational status (e.g., Banerjee \& Mai, 2014; Miller \& Neo, 1997). It was rationalized that skilled migrants became more proficient in the language after several months of residence in the host country (van Riemsdijk, 2013); and that multiple job changes over long time periods (e.g., two decades after arrival) eventually help skilled migrants find their desired position (e.g., Liversage, 2009).

Outcomes of qualification-matched employment

Earnings. Twenty-one studies examined variables related to skilled migrants' earnings in the host country. One dominant pattern across the reviewed studies was that in many cases skilled migrants' qualification-matched employment led to earnings identical to or higher than their home country counterparts (e.g., Cortes \& Pan, 2015; Harvey, 2012; Kaushal, Lu, Denier, Wang, \& Trejo, 2016; Lopez, 2012; Luthra, 2009; Varma, 2010). Studies attributed the pattern of higher payments to skilled migrants' high productivity (Albarran, Carrasco, \& Ruiz-Castillo, 2017; Corley \& Sabharwal, 2007; Scellato, Franzoni, \& Stephan, 2015), representation in highly-paid disciplines (Owusu \& Sweetman, 2015; 
Tang, 1993), residence in regions of high income concentration such as large metropolitan areas (Lin et al., 2009), and more years of schooling than natives (Espenshade et al., 2001).

The second pattern that emerged from the studies suggested that a mismatch between migrants' educational attainments and their job requirements had a negative association with their earnings (McDonald \& Valenzuela, 2017). In addition, wages of skilled migrants who started employment in low-paid jobs could not catch up with that of their native peers (Weiss et al., 2003).

Job satisfaction. Twelve Studies focused on skilled migrants' job satisfaction, which ranged from low to high (e.g., de Vries et al., 2016). While some studies reported that skilled migrants expressed lower levels of job satisfaction in academic contexts (Corley \& Sabharwal, 2007; Sabharwal, 2011a; Sabharwal, 2011b), others reported that skilled immigrants were relatively satisfied with their work once their chances of obtaining qualification-matched employment increased (Kuusio et al., 2014). Studies argued that poor working conditions, a lack of career advancement opportunities, low employer support, and lower pay compared to native workers accounted for job dissatisfaction (e.g., Corley \& Sabharwal, 2007; Lin et al., 2009; Trlin, 2012; Varma, 2010).

Mental health. Eight studies included mental health variables in their study of skilled migrants' employment in the host country. The dominant pattern across these studies was that skilled migrants without qualification-matched employment were more likely to experience mental health problems. For example, findings of the reviewed studies showed that lengthy job searches and the inability to find employment fitting their skill levels resulted in stress, anxiety, depression, and unhappiness for skilled migrants (e.g., Axelsson, 2017; Dean \& Wilson, 2009). Even skilled migrants who had qualification-matched jobs reported a higher risk of burnout and poorer workability compared to native professionals (Aalto et al., 2014). 
Professional de-skilling. Seven studies showed that skilled migrants who could not obtain qualification-matched employment felt that they became professionally de-skilled (Adhikari \& Melia, 2015; Aure, 2013; Bidwell et al., 2014; Dean \& Wilson, 2009; Humphries et al., 2013). This de-skilling involved losing skills by working in entry-level positions in their profession (Adhikari \& Melia, 2015; Humphries et al., 2013), or working in un-skilled jobs (Bidwell et al., 2014; Yeoh \& Willis, 2005).

\section{Moderator of the relationship between qualification-matched employment and its outcomes}

Job tenure. Reviewed studies showed that the more time skilled migrants spent in jobs that did not use their qualifications, the more likely they were to report mental health problems and stress (Reid, 2012; Subedi \& Rosenberg, 2016). Other studies suggested that wages of skilled migrants who started their employment in low-paid jobs-qualificationunmatched employment - could not catch up with that of their native peers (Weiss et al., 2003).

\section{Discussion}

The purpose of this review was to synthesize the empirical research on skilled migrants' qualification-matched employment across multiple disciplines. We took a first step towards setting the stage for theory development by integrating findings of the reviewed studies into a conceptual model. Our model specifies antecedent, outcome, and moderating variables associated with qualification-matched employment of skilled migrants in their host country. Below, we describe our contributions and provide pathways for future research.

Previous reviews on skilled migrants within management literature (Crowley-Henry et al., 2016; Syed, 2008) have focused on migrants' careers - generically defined as workrelated experiences — whereas our analysis focused on qualification-matched employment based on extant literature across 10 different disciplines. In the skilled migration context, obtaining qualification-matched employment is of interest to both the host country and the 
skilled immigrant. Our study presents a conceptual model that paves the way for further investigations on this topic.

We contribute to highlighting the multi-level nature of factors contributing to skilled migrants' access to qualification-matched employment by identifying 12 factors at individual, organizational, host country national, and international levels associated with skilled migrants' qualification-matched or qualification-unmatched employment in the host country. In doing so, we address the paradox of why skilled migrants - despite possessing the necessary skills - may not find employment commensurate with their qualifications.

At multiple levels, our review identifies antecedents that were not discussed in previous reviews of skilled migrant research in management and HRM fields (e.g., CrowleyHenry et al., 2016). At the individual-level, our findings add nuances to human capital factors such as education discussed in previous reviews (Syed, 2008) and elaborate on their link to obtaining employment fitting skilled migrants' qualifications. For example, our findings suggest that educational credentials, work experience, and professional networks are linked to qualification-matched employment only when obtained in the host country.

At the host country national-level, the inclusion of research published in different disciplines led to identifying a factor we labelled as host country government integration initiatives, which was examined by occupational health researchers (e.g., Kuusio et al., 2014). We also identified a professional qualification recognition variable studied across demography (Hawthorne, 1997), geography (Girard \& Bauder, 2007), and sociology (Thondhlana et al., 2016). Recognizing the importance of such initiatives, future scholars can develop experimental designs to capture the impact of such initiatives in more systematically to better inform policy and practice.

At the international-level, we identified a variable - political relationships between home and host country — which has potential to impact skilled migrants' qualification- 
matched employment and is unique, as it steps beyond the three commonly discussed micro-, meso-, and macro-level factors (Syed, 2008). We believe this variable to be of great significance given the ongoing political unrest in multiple regions of the world (Guéhenno, 2017). Researchers in geography and demography have examined the association of global events such as the Second World War (Batnitzky \& McDowell, 2011), accession to the European Union (van Riemsdijk, 2013), and terrorist attacks (Hawthorne, 2010) and skilledworker access to qualification-matched employment. HRM scholars may also consider international-level factors while examining skilled migrant employment. The recent calls for papers regarding the contributions of the Brexit vote, Trump administration (Robinson \& Bristow, n.d.), and Syrian refugee crisis (Richardson, Karam, \& Afiouni, n.d.) in management journals indicate an emerging interest in significant international level events on migrant work situations. HRM scholars focusing on skilled migrants' careers need to examine the implications of such political changes for skilled migrants' professional lives.

Another noteworthy contribution of our review is identifying four variables that moderate the association between skilled migrants' qualification-matched employment and its antecedents. It is interesting that except for gender, which was present in studies across all disciplines, other moderating variables received attention from scholars in only certain disciplines. For example, effects of length of residence in the host country were shown in longitudinal studies conducted by economists and demographers (e.g., Kler, 2006; Weiss et al., 2003), and individual agency was emphasized by management scholars (e.g., Al Ariss et al., 2013). Providing these moderators in a single model will help scholars employ insights from other disciplines in their future work concerned with skilled migrants. We encourage HRM researchers to explore the moderating effects of these variables in the relationships between migrants' qualification-matched employment and its outcomes, as a limited number of studies have focused on their effects. 
Most of the studies included in our review focused on antecedents and not on outcomes of skilled immigrants' qualification-matched employment. Future studies need to focus on outcomes, not only for skilled migrants, but also for their families, peers, employers, and wider communities in both their home and host countries. We observed that skilled migrants were equally-paid or had higher earnings than their host country native counterparts. This finding deserves further exploration by future research. Also, fewer studies examined the benefits packages or mechanisms impacting skilled migrants' pay. Future scholars can bridge this gap and expand the research on outcome variables of interest to HRM scholars and practitioners who work with skilled migrants.

Finally, our findings contribute to HRM scholarship on skilled migration by paving the way for future quantitative research. We present measurable variables (antecedents, outcomes, and moderating variables), in contrast to previous reviews that adopted a descriptive approach. Our findings are critical to HRM research, as a recent review found that qualitative outnumber quantitative studies conducted on skilled migrants and published in management journals (Crowley-Henry et al., 2016). Our conceptual model can inspire quantitative scholars to develop measures for concepts we propose and to examine relationships among variables included in the model. We also noticed that $81 \%$ ( 40 out 49 studies) of the quantitative studies in our review used pre-existing data from national immigrant surveys (e.g., Mukhopadhyay \& Oxborrow, 2012; Vidal-Coso \& Miret-Gamundi, 2014), census data (e.g., Harvey, 2012; Kler, 2006), longitudinal labor market surveys (e.g., Kaushal et al., 2016; Vargas-Silva, 2016), and data sets of national registered professionals (e.g., Battu, Seaman, \& Zenou, 2011) to study antecedents or outcomes of skilled migrants' qualification-matched employment. Therefore, our findings can inform further quantitative research to explore new variables and relationships in regards to skilled migrants' employment. 


\section{Practical Implications}

Our review combines the findings of previous studies, half of which were exploratory; therefore, our findings are subject to further testing, and we cannot claim that all our findings are generalizable to all skilled migrants. In addition, due to the scattered nature of the reviewed studies, we were not able to conduct a quantitative meta-analysis among the quantitative studies included in the review. However, insights gained from our model have several practical implications for HR practitioners working with skilled migrants, skilled migrants themselves, those who aspire to immigrate, and legal authorities in host countries accommodating skilled migrants.

Many of the variables that shape skilled migrants' qualification-matched or unmatched employment experiences can be managed by HR professionals if known to them. For example, knowledge about their host country culture was a concern for many skilled migrants and deprived them of making connections, networking, and obtaining qualificationmatched employment. HR professionals can solve this issue by providing training and mentoring programs that focus on familiarizing skilled migrants with their host country's culture, work procedures, and professional norms. Language training can also be provided as part of orientation for valued professional talent. Induction and initial development programs can be tailored to accommodate both varying conditions of different home countries and individual skilled migrant needs. HR professionals can also access and apply qualification and training equivalency guides. This will help target recruitment and inform selection decisions, and will also help in providing tailored advice to skilled migrants on future development needs and career progression. Finally, HR professionals can consider individual variables that might affect migrants' employment experience, as well as intervening variables such as gender, in planning and preparing to recruit skilled migrants. 
Skilled migrants, or those who plan to immigrate, can better prepare themselves by learning about variables that might affect their qualification-matched employment after immigration. This might inform skilled migrants' decisions about which countries to consider for immigration. For example, equivalency and recognition of qualifications could be a significant factor in such decisions. Once a host country is decided on, additional actions can be taken. For instance, learning about the significant role of language proficiency might lead to potential immigrants' increased investment in mastering the preferred host country's language. This may extend to learning more about cultural norms in relation to work and employment within the chosen host country. Overall, having a realistic picture of employment after immigration might change, delay, or stop some individuals' immigration plans or decisions.

Countries seeking skilled migrants can design interventions to pave the way for skilled migrants' qualification-matched employment. These include formulation of immigration and visa policies and procedures, adjusting employment policies, reinforcing equality and diversity initiatives, and supporting high-quality language programs as examples of the many actions that host countries can take. They also can use this model to further explore skilled migrant employment in their country by funding studies to clarify the role of various factors in migrants' qualification-matched employment.

\section{References}

Note: References marked with an asterisk indicate the studies included in this review.

*Aalto, A., Heponiemi, T., Keskimaki, I., Kuusio, H., Hietapakka, L., Lamsa, R., . . . Elovainio, M. (2014). Employment, psychosocial work environment and well-being among migrant and native physicians in Finnish health care. European Journal of Public Health, 24(3), 445-451. doi:10.1093/eurpub/cku021 
*Adhikari, R., \& Melia, K. M. (2015). The (mis)management of migrant nurses in the UK: A sociological study. Journal of Nursing Management, 23(3), 359-367. doi:10.1111/jonm.12141

*Agullo, B., \& Egawa, M. (2009). International careers of Indian workers in Tokyo examination and future directions. Career Development International, 14(2-3), 148-168. doi:10.1108/13620430910950755

Al Ariss, A., \& Crowley-Henry, M. (2013). Self-initiated expatriation and migration in the management literature: Present theorizations and future research directions. Career Development International, 18(1), 78-96.

Al Ariss, A., Koall, I., Ozbilgin, M., Suutari, V., Al Ariss, A., Koall, I., . . Suutari, V. (2012). Careers of skilled migrants: Towards a theoretical and methodological expansion. Journal of Management Development, 31(2), 92-101.

Al Ariss, A., \& Syed, J. (2011). Capital mobilization of skilled migrants: A relational perspective. British Journal of Management, 22(2), 286-304.

*Al Ariss, A., Vassilopoulou, J., Oezbilgin, M. F., \& Game, A. (2013). Understanding career experiences of skilled minority ethnic workers in France and Germany. International Journal of Human Resource Management, 24(6), 1236-1256. doi:10.1080/09585192.2012.709190

Al Ariss, Makela, \& De Cieri, (2015). Advancing the understanding of inflow and outflow of international labour in management research: European and global perspectives. Retrieved from http://division.aomonline.org/gdo/newsletters/Newsletter_2015_Volume17 issue2text.p $\underline{\mathrm{df}}$ 
*Alarcon, R. (1999). Recruitment processes among foreign-born engineers and scientists in Silicon Valley. American Behavioral Scientist, 42(9), 1381-1397. doi:10.1177/00027649921954958

*Albarran, P., Carrasco, R., \& Ruiz-Castillo, J. (2017). Are migrants more productive than stayers? Some evidence from a set of highly productive academic economists. Economic Inquiry, 55(3), 1308-1323. doi:10.1111/ecin.12430

*Aure, M. (2013). Highly skilled dependent migrants entering the labour market: Gender and place in skill transfer. Geoforum, 45, 277-286. doi:10.1016/j.geoforum.2012.11.015

*Axelsson, L. (2017). Living within temporally thick borders: IT professionals' experiences of Swedish immigration policy and practice. Journal of Ethnic and Migration Studies, 43(6), 974-990. doi:10.1080/1369183X.2016.1200966

*Bahn, S. (2014). Migrant workers on temporary 457 visas working in Australia: Implications for human resource management. Asia Pacific Journal of Human Resources, 52(1), 7792. doi:10.1111/1744-7941.12018

*Banerjee, R., \& Mai Phan. (2014). Licensing requirements and occupational mobility among highly skilled new immigrants in Canada. Relations Industrielles-Industrial Relations, 69(2), 290-315.

*Batnitzky, A., \& McDowell, L. (2011). Migration, nursing, institutional discrimination and emotional/affective labour: Ethnicity and labour stratification in the UK National Health Service. Social \& Cultural Geography, 12(2), 181-201. doi:10.1080/14649365.2011.545142

*Battu, H., Seaman, P., \& Zenou, Y. (2011). Job contact networks and the ethnic minorities. Labour Economics, 18(1), 48-56.

Bauder, H. (2014). Domicile citizenship, human mobility and territoriality. Progress in Human Geography, 38(1), 91-106. 
*Bazillier, R., \& Boboc, C. (2016). Labour migration as a way to escape from employment vulnerability? Evidence from the European union. Applied Economics Letters, 23(16), 1149-1152. doi:10.1080/13504851.2016.1139670

Becker, G.S. (1964). Human capital: a theoretical and empirical analysis, with special reference to education. New York: National Bureau of Economic Research.

*Beckhusen, J., Florax, R. J. G. M., Poot, J., \& Waldorf, B. S. (2013). Attracting global talent and then what? Overeducated immigrants in the United States. Journal of Regional Science, 53(5), 834-854. doi:10.1111/jors. 12030

*Beladi, H., \& Kar, S. (2015). Skilled and unskilled immigrants and entrepreneurship in a developed country. Review of Development Economics, 19(3), 666-682. doi:10.1111/rode. 12155

*Bidwell, P., Laxmikanth, P., Blacklock, C., Hayward, G., Willcox, M., Peersman, W., .. . Mant, D. (2014). Security and skills: The two key issues in health worker migration. Global Health Action, 7, 1-10. doi:10.3402/gha.v7.24194

Birks, M., and J. Mills. 2011. Grounded theory: A practical guide. Thousand Oaks: Sage.

*Blackmore, J., Gribble, C., \& Rahimi, M. (2017). International education, the formation of capital and graduate employment: Chinese accounting graduates' experiences of the Australian labour market. Critical Studies in Education, 58(1), 69-88. doi:10.1080/17508487.2015.1117505

*Blitz, B. K. (2005). 'Brain circulation': the Spanish medical profession and international medical recruitment in the United Kingdom. Journal of European Social Policy, 15(4), $363-379$.

*Blume-Kohout, M. E. (2016). Why are some foreign-born workers more entrepreneurial than others? Journal of Technology Transfer, 41(6), 1327-1353. doi:10.1007/s10961015-9438-3 
*Boese, M., Campbell, I., Roberts, W., \& Tham, J. (2013). Temporary migrant nurses in australia: Sites and sources of precariousness. Economic and Labour Relations Review, 24(3), 316-339. doi:10.1177/1035304613496500

Bourdieu, P. (1984). Distinction: A social critique of the judgement of taste. Cambridge, MA: Harvard University Press.

Bourdieu, P. (1977). Outline of a theory of practice. Cambridge: Cambridge University Press. Bourdieu, P. (2005). The social structures of the economy. Cambridge: Polity Press.

*Bornat, J., Henry, L., \& Raghuram, P. (2011). The making of careers, the making of a discipline: Luck and chance in migrant careers in geriatric medicine. Journal of Vocational Behavior, 78(3), 342-350. doi:10.1016/j.jvb.2011.03.015

*Boyd, M., \& Thomas, D. (2001). Match or mismatch? The employment of immigrant engineers in Canada's labor force. Population Research and Policy Review, 20(1-2), 107-133. doi:10.1023/A:1010625515456

*Bruland, S. K., \& Rusten, G. (2012). Sourcing strategies, channels and geographies in the international recruitment of a highly skilled work-force: A case study of companies in the petroleum and maritime sectors in a non-urban location in Norway. Erdkunde, 66(1), 1-11. doi:10.3112/erdkunde.2012.01.01

${ }^{*}$ Cantwell, B., \& Taylor, B. J. (2013). Internationalization of the postdoctorate in the United States: Analyzing the demand for international postdoc labor. Higher Education, 66(5), 551-567. doi:10.1007/s10734-013-9621-0

Cerdin, J. L., Diné, M. A., \& Brewster, C. (2014). Qualified immigrants’ success: Exploring the motivation to migrate and to integrate. Journal of International Business Studies, $45(2), 151-168$. 
*Cerdin, J., Dine, M. A., \& Brewster, C. (2014). Qualified immigrants' success: Exploring the motivation to migrate and to integrate. Journal of International Business Studies, 45(2), 151-168. doi:10.1057/jibs.2013.45

${ }^{*}$ Coates, K., \& Carr, S. (2005). Skilled immigrants and selection bias: A theory-based field study from New Zealand. International Journal of Intercultural Relations, 29(5), 577599. doi:10.1016/j.ijintrel.2005.05.001

*Cooke, F. L., Zhang, J., \& Wang, J. (2013). Chinese professional immigrants in Australia: A gendered pattern in (re)building their careers. International Journal of Human Resource Management, 24(13), 2628-2645. doi:10.1080/09585192.2012.750615

*Corley, E. A., \& Sabharwal, M. (2007). Foreign-born academic scientists and engineers: Producing more and getting less than their US-born peers? Research in Higher Education, 48(8), 909-940. doi:10.1007/s11162-007-9055-6

*Cortes, P., \& Pan, J. (2015). The relative quality of foreign-educated nurses in the United States. Journal of Human Resources, 50(4), 1009-1050.

Crowley $\square$ Henry, M., O'Connor, E., \& Al Ariss, A. (2016). Portrayal of Skilled Migrants' Careers in Business and Management Studies: A Review of the Literature and Future Research Agenda. European Management Review.

*Das Gupta, T., Man, G., Mirchandani, K., \& Ng, R. (2014). Class borders: Chinese and south Asian Canadian professional women navigating the labor market. Asian and Pacific Migration Journal, 23(1), 55-83.

*de Vries, D. H., Steinmetz, S., \& Tijdens, K. G. (2016). Does migration 'pay off' for foreignborn migrant health workers? An exploratory analysis using the global Wage Indicator dataset. Human Resources for Health, 14, 40. doi:10.1186/s12960-016-0136-5

*Dean, J. A., \& Wilson, K. (2009). 'Education? It is irrelevant to my job now. it makes me very depressed ': Exploring the health impacts of under/unemployment among highly 
skilled recent immigrants in Canada. Ethnicity \& Health, 14(2), 185-204. doi: $10.1080 / 13557850802227049$

"DelCampo, R. G., Jacobson, K. J. L., Van Buren,Harry J.,„III, \& Blancero, D. M. (2011). Comparing immigrant and US born Hispanic business professionals insights on discrimination. Cross Cultural Management-an International Journal, 18(3), 327-350. doi:10.1108/13527601111152851

*Dell'Aringa, C., \& Pagani, L. (2011). Labour market assimilation and over-education: The case of immigrant workers in Italy. Economia Politica, 28(2), 219-240.

"Dietz, J., Joshi, C., Esses, V. M., Hamilton, L. K., \& Gabarrot, F. (2015). The skill paradox: Explaining and reducing employment discrimination against skilled immigrants. International Journal of Human Resource Management, 26(10), 1318-1334. doi:10.1080/09585192.2014.990398

*Edge, J. S., \& Hoffman, S. J. (2013). Empirical impact evaluation of the WHO global code of practice on the international recruitment of health personnel in Australia, Canada, UK and USA. Globalization and Health, 9, 60. doi:10.1186/1744-8603-9-60

"Espenshade, T., Usdansky, M., \& Chung, C. (2001). Employment and earnings of foreignborn scientists and engineers. Population Research and Policy Review, 20(1-2), 81-105. doi:10.1023/A:1010660808072

*Farrer, J. (2014). China wants you: The social construction of skilled labor in three employment sectors. Asian and Pacific Migration Journal, 23(4), 397-420.

"Felker, J. A. (2012). EU's new member states: An untapped (and underappreciated) source of talent for MNCs? International Journal of Human Resource Management, 23(2), 255277. doi:10.1080/09585192.2011.606112 
*Fernando, W. D. A., \& Cohen, L. (2016). Exploring career advantages of highly skilled migrants: A study of Indian academics in the UK. International Journal of Human Resource Management, 27(12), 1277-1298. doi:10.1080/09585192.2015.1072101

*Fossland, T. (2013). Crossing borders - getting work: Skilled migrants' gendered labour market participation in norway. Norsk Geografisk Tidsskrift-Norwegian Journal of Geography, 67(5), 276-283. doi:10.1080/00291951.2013.847854

*Francis, K., Chapman, Y., Doolan, G., Sellick, K., \& Barnett, T. (2008). Using overseas registered nurses to fill employment gaps in rural health services: Quick fix or sustainable strategy? Australian Journal of Rural Health, 16(3), 164-169. doi:10.1111/j.1440-1584.2008.00967.x

*Gandini, L., \& Lozano-Ascencio, F. (2016). The effects of the crisis on occupational segregation of skilled migrants from Latin America and the Caribbean in the United States, 2006-2012. Population Space and Place, 22(5), 441-456. doi:10.1002/psp.1909

*Girard, E. R., \& Bauder, H. (2007). Assimilation and exclusion of foreign trained engineers in Canada: Inside a professional regulatory organization. Antipode, 39(1), 35-53. doi:10.1111/j.1467-8330.2007.00505.x

*Green, C., Kler, P., \& Leeves, G. (2007). Immigrant overeducation: Evidence from recent arrivals to Australia. Economics of Education Review, 26(4), 420-432. doi:10.1016/j.econedurev.2006.02.005

*Groutsis, D., \& Arnold, P. C. (2012). Tracking the career decisions and experience of migrant elites: The case of south African-trained medical professionals in the Australian labour market. Health Sociology Review, 21(3), 332-342.

Guéhenno, Jean-Marie. (2017). 10 Conflicts to Watch in 2017. Retrieved form https://www.crisisgroup.org/global/10-conflicts-watch-2017 
*Guerrero, L., \& Rothstein, M. G. (2012). Antecedents of underemployment: Job search of skilled immigrants in Canada. Applied Psychology-an International Review-Psychologie Appliquee-Revue Internationale, 61(2), 323-346. doi:10.1111/j.1464-0597.2011.00470.x

Guo, C., \& Al Ariss, A. (2015). Human resource management of international migrants: Current theories and future research. The International Journal of Human Resource Management, 26(10), 1287-1297.

*Hardill, I., \& MacDonald, S. (2000). Skilled international migration: The experience of nurses in the UK. Regional Studies, 34(7), 681-692.

*Harris, A. (2014). Encountering the familiar unknown: The hidden work of adjusting medical practice between local settings. Journal of Contemporary Ethnography, 43(3), 259-282. doi:10.1177/0891241613494810

*Harvey, W. S. (2008). Strong or weak ties? British and Indian expatriate scientists finding jobs in Boston. Global Networks-a Journal of Transnational Affairs, 8(4), 453-473. doi:10.1111/j.1471-0374.2008.00234.x

*Harvey, W. S. (2012). Labour market experiences of skilled British migrants in Vancouver. Employee Relations, 34(6), 658-669. doi:10.1108/01425451211267900

*Hawthorne, L. (1997). The question of discrimination: Skilled migrants' access to Australian employment. International Migration, 35(3), 395-419. doi:10.1111/1468-2435.00019

*Hawthorne, L. (2010). How valuable is "two-step migration"? Labor market outcomes for international student migrants to Australia. Asian and Pacific Migration Journal, 19(1), $5-36$.

Higgins, J. P., \& Green, S. (Eds.). (2011). Cochrane handbook for systematic reviews of interventions. Sussex: John Wiley \& Sons.

*Horverak, J. G., Sandal, G. M., Bye, H. H., \& Pallesen, S. (2013). Managers' selection preferences: The role of prejudice and multicultural personality traits in the assessment 
of native and immigrant job candidates. European Review of Applied Psychology-Revue Europeenne De Psychologie Appliquee, 63(5), 267-275. doi:10.1016/j.erap.2013.07.003

*Humphries, N., Tyrrell, E., McAleese, S., Bidwell, P., Thomas, S., Normand, C., \& Brugha, R. (2013). A cycle of brain gain, waste and drain - a qualitative study of non-EU migrant doctors in Ireland. Human Resources for Health, 11, 63. doi:10.1186/1478-4491-11-63

*Joseph, M. G. C. (2016). From students to permanent residents: The role of social networks in the immigration transition of Indians in New Zealand. Asian and Pacific Migration Journal, 25(2), 168-190. doi:10.1177/0117196816640988

*Kangasniemi, M., Winters, L. A., \& Commander, S. (2007). Is the medical brain drain beneficial? Evidence from overseas doctors in the UK. Social Science \& Medicine, 65(5), 915-923. doi:10.1016/j.socscimed.2007.04.021

*Kaushal, N., Lu, Y., Denier, N., Wang, J. S., \& Trejo, S. J. (2016). Immigrant employment and earnings growth in Canada and the USA: Evidence from longitudinal data. Journal of Population Economics, 29(4), 1249-1277. doi:10.1007/s00148-016-0600-5

*Khoo, S., Voigt-Graf, C., McDonald, P., \& Hugo, G. (2007). Temporary skilled migration to Australia: Employers' perspectives. International Migration, 45(4), 175-201. doi:10.1111/j.1468-2435.2007.00423.x

${ }^{*}$ Kim, E., Hogge, I., Mok, G., \& Nishida, H. (2014). Work experiences of foreign-born Asian women counseling and psychology faculty. Journal of Multicultural Counseling and Development, 42(3), 147-160. doi:10.1002/j.2161-1912.2014.00051.x

*Kler, P. (2006). Graduate overeducation and its effects among recently arrived immigrants to Australia: A longitudinal survey. International Migration, 44(5), 93-128. doi:10.1111/j.1468-2435.2006.00388.x 
*Klingler, C., \& Marckmann, G. (2016). Difficulties experienced by migrant physicians working in German hospitals: A qualitative interview study. Human Resources for Health, 14, 57. doi:10.1186/s12960-016-0153-4

*Kuusio, H., Lamsa, R., Aalto, A., Manderbacka, K., Keskimaki, I., \& Elovainio, M. (2014). Inflows of foreign-born physicians and their access to employment and work experiences in health care in Finland: Qualitative and quantitative study. Human Resources for Health, 12, 41. doi:10.1186/1478-4491-12-41

*Lin, Z., Pearce, R., \& Wang, W. (2009). Imported talents: Demographic characteristics, achievement and job satisfaction of foreign born full time faculty in four-year American colleges. Higher Education, 57(6), 703-721. doi:10.1007/s10734-008-9171-z

Lincoln, Y. S. \& E. Guba. 1985. Naturalistic inquiry. Thousand Oaks: Sage.

Liu, Y., \& Xu, W. (2017). Destination choices of permanent and temporary migrants in China, 1985-2005. Population, Space and Place, 23(1).

*Liversage, A. (2009). Vital conjunctures, shifting horizons: High-skilled female immigrants looking for work. Work Employment and Society, 23(1), 120-141. doi:10.1177/0950017008099781

*Lopez, M. J. (2012). Skilled immigrant women in the US and the double earnings penalty. Feminist Economics, 18(1), 99-134. doi:10.1080/13545701.2012.658429

*Luthra, R. R. (2009). Temporary immigrants in a high-skilled labour market: A study of H1Bs. Journal of Ethnic and Migration Studies, 35(2), 227-250. doi:10.1080/13691830802586237

*Mahmud, S., Alam, Q., \& Haertel, C. (2014). Mismatches in skills and attributes of immigrants and problems with workplace integration: A study of IT and engineering professionals in Australia. Human Resource Management Journal, 24(3), 339-354. doi:10.1111/1748-8583.12026 
*Mattoo, A., Neagu, I. C., \& Oezden, C. (2008). Brain waste? Educated immigrants in the US labor market. Journal of Development Economics, 87(2), 255-269. doi:10.1016/j.jdeveco.2007.05.001

*McDonald, J. T., \& Valenzuela, M. R. (2017). How does skills mismatch affect remittances? A study of Filipino migrant workers. Contemporary Economic Policy, 35(1), 216-231. doi:10.1111/coep. 12167

*Miller, P., \& Neo, L. (1997). Immigrant unemployment: The Australian experience. International Migration, 35(2), 155-185. doi:10.1111/1468-2435.00009

Mincer, J. (1974). Schooling, experience and earnings. New York: Columbia University Press.

*Mucha, J., \& Luczaj, K. (2014). Foreigners in the polish academic system at the beginning of the 21st century. A quantitative analysis of their employment according to the official documents. Polish Sociological Review, (185), 113-130.

*Mukhopadhyay, S., \& Oxborrow, D. (2012). The value of an employment-based green card. Demography, 49(1), 219-237. doi:10.1007/s13524-011-0079-3

*Mulholland, J., \& Ryan, L. (2014). Doing the business: Variegation, opportunity and intercultural experience among intra-EU highly-skilled migrants. International Migration, 52(3), 55-68. doi:10.1111/imig.12120

*Munoz-Comet, J. (2016). Potential work experience as protection against unemployment: Does it bring equal benefit to immigrants and native workers? European Sociological Review, 32(5), 537-551. doi:10.1093/esr/jcv137

*Myles, J., Cheng, L., \& Wang, H. (2006). Teaching in elementary school: Perceptions of foreign-trained teacher candidates on their teaching practicum. Teaching and Teacher Education, 22(2), 233-245. doi:10.1016/j.tate.2005.09.001 
OECD. (2013). World Migration in Figures. Retrieved from https://www.oecd.org/els/mig/World-Migration-in-Figures.pdf

OECD. (2014). Is migration good for the economy? Retrieved from https://www.oecd.org/migration/OECD\%20Migration\%20Policy\%20Debates\%20Num ero\%202.pdf

*Oreopoulos, P. (2011). Why do skilled immigrants struggle in the labor market? A field experiment with thirteen thousand resumes. American Economic Journal-Economic Policy, 3(4), 148-171. doi:10.1257/pol.3.4.148

*Owusu, Y., \& Sweetman, A. (2015). Regulated health professions: Outcomes by place of birth and training. Canadian Public Policy-Analyse De Politiques, 41, S98-S115.

*Peterson, B. D., Pandya, S. S., \& Leblang, D. (2014). Doctors with borders: Occupational licensing as an implicit barrier to high skill migration. Public Choice, 160(1-2), 45-63. doi:10.1007/s11127-014-0152-8

*Reid, A. (2012). Under-use of migrants' employment skills linked to poorer mental health. Australian and New Zealand Journal of Public Health, 36(2), 120-125. doi:10.1111/j.1753-6405.2012.00842.x

*Riano, Y. (2011). Drawing new boundaries of participation: Experiences and strategies of economic citizenship among skilled migrant women in Switzerland. Environment and Planning A, 43(7), 1530-1546. doi:10.1068/a4374

Richardson, J. Karam, C. \& Afiouni, F. (n.d.). The Impact of the Global Refugee Crisis on the Career Ecosystem: Special issue call for papers from Career Development International. Retrieved from http://www.emeraldgrouppublishing.com/products/journals/call_for_papers.htm?id=697 8 
Robinson S. \& Bristow A., (n.d.). Populist Responses to Austerity and Cultural Change:

Brexit, Trumpism and Beyond, Retrieved from http://journals.sagepub.com/pbassets/cmscontent/ORG/CFP-Populist-Responses.pdf

*Sabharwal, M. (2011). High-skilled immigrants: How satisfied are foreign-born scientists and engineers employed at American universities? Review of Public Personnel Administration, 31(2), 143-170. doi:10.1177/0734371X11408572

*Sabharwal, M. (2011). Job satisfaction patterns of scientists and engineers by status of birth. Research Policy, 40(6), 853-863. doi:10.1016/j.respol.2011.04.002

${ }^{*}$ Scellato, G., Franzoni, C., \& Stephan, P. (2015). Migrant scientists and international networks. Research Policy, 44(1), 108-120. doi:10.1016/j.respol.2014.07.014

Shaw, J. D., \& Gruber, M. (2017). New Ways of Seeing: Elaboration on a Theme. Academy of Management Journal, 60(2), 397-401.

*Shinozaki, K. (2014). Career strategies and spatial mobility among skilled migrants in Germany: The role of gender in the work-family interaction. Tijdschrift Voor Economische En Sociale Geografie, 105(5), 526-541. doi:10.1111/tesg.12111

Strauss, A. \& Corbin, J. M.. (1990). Basics of qualitative research: Grounded theory procedures and techniques. Thousand Oaks: Sage.

Strauss, K., \& McGrath, S. (2017). Temporary migration, precarious employment and unfree labour relations: Exploring the 'continuum of exploitation'in Canada's Temporary Foreign Worker Program. Geoforum, 78, 199-208.

*Subedi, R. P., \& Rosenberg, M. W. (2016). High-skilled immigrants low-skilled jobs: Challenging everyday health. Canadian Geographer-Geographe Canadien, 60(1), 5668. doi:10.1111/cag. 12237

Syed, J. (2008). Employment prospects for skilled migrants: A relational perspective. Human Resource Management Review, 18(1), 28-45. 
*Szarucki, M., Brzozowski, J., \& Stankeviciene, J. (2016). Determinants of self-employment among polish and Romanian immigrants in Germany. Journal of Business Economics and Management, 17(4), 598-612. doi:10.3846/16111699.2016.1202313

*Tang, J. (1993). The career attainment of Caucasian and Asian engineers. Sociological Quarterly, 34(3), 467-496. doi:10.1111/j.1533-8525.1993.tb00122.x

*Thondhlana, J., Madziva, R., \& McGrath, S. (2016). Negotiating employability: Migrant capitals and networking strategies for Zimbabwean highly skilled migrants in the UK. Sociological Review, 64(3), 575-592. doi:10.1111/1467-954X.12373

*Trlin, A. (2012). "It's all so different here ... ": Initial employment and social engagement experiences of south Africans in New Zealand. Asian and Pacific Migration Journal, $21(1), 57-81$.

Turchick Hakak, L., \& Al Ariss, A. (2013). Vulnerable work and international migrants: A relational human resource management perspective. The International Journal of Human Resource Management, 24(22), 4116-4131.

*Tzeng, R. (2010). Cultural capital and cross-border career ladders western professional migrants in Taiwan. International Sociology, 25(1), 123-143. doi:10.1177/0268580909346709

${ }^{*}$ Van Laer, K., \& Janssens, M. (2017). Agency of ethnic minority employees: Struggles around identity, career and social change. Organization, 24(2), 198-217. doi:10.1177/1350508416664143

*van Riemsdijk, M. (2013). Everyday geopolitics, the valuation of labour and the sociopolitical hierarchies of skill: Polish nurses in Norway. Journal of Ethnic and Migration Studies, 39(3), 373-390. doi:10.1080/1369183X.2013.733859

*Vargas-Silva, C. (2016). Highly skilled migrant workers and the UK business cycle. Population Space and Place, 22(5), 457-470. doi:10.1002/psp.1867 
*Varma, R. (2010). India-born in the US science and engineering workforce. American Behavioral Scientist, 53(7), 1064-1078. doi:10.1177/0002764209356239

*Velayutham, S. (2013). Precarious experiences of Indians in Australia on 457 temporary work visas. Economic and Labour Relations Review, 24(3), 340-361. doi: $10.1177 / 1035304613495268$

*Vidal-Coso, E., \& Miret-Gamundi, P. (2014). The labour trajectories of immigrant women in Spain: Are there signs of upward social mobility? Demographic Research, 31, 337-379. doi:10.4054/DemRes.2014.31.13

*Webb, S. (2015). 'It's who you know not what': Migrants' encounters with regimes of skills as misrecognition. Studies in Continuing Education, 37(3), 267-285. doi:10.1080/0158037X.2015.1007938

*Weiss, Y., Sauer, R., \& Gotlibovski, M. (2003). Immigration, search, and loss of skill. Journal of Labor Economics, 21(3), 557-591. doi:10.1086/374959

${ }^{*}$ Weller, S. A. (2017). Accounting for skill shortages? Migration and the Australian labour market. Population Space and Place, 23(2), e1997. doi:10.1002/psp.1997

${ }^{*}$ Winterheller, J., \& Hirt, C. (2017). Career patterns of young highly skilled migrants from southeast Europe in Austria. Personnel Review, 46(2), 222-236. doi:10.1108/PR-052015-0148

*Wright, A., Regan, M., Haigh, C., Sunderji, I., Vijayakumar, P., Smith, C., \& Nestel, D. (2012). Supporting international medical graduates in rural Australia: A mixed methods evaluation. Rural and Remote Health, 12(1), 1897.

Wright, C. F. (2014). How do states implement liberal immigration policies? Control signals and skilled immigration reform in Australia. Governance, 27(3), 397-421. 
*Wright, R., Ellis, M., \& Townley, M. (2017). The matching of STEM degree holders with STEM occupations in large metropolitan labor markets in the United States. Economic Geography, 93(2), 185-201.

*Yeoh, B., \& Willis, K. (2005). Singaporeans in china: Transnational women elites and the negotiation of gendered identities. Geoforum, 36(2), 211-222.

doi:10.1016/j.geoforum.2003.07.004

Zikic, J. (2015). Skilled migrants' career capital as a source of competitive advantage: implications for strategic HRM. The International Journal of Human Resource Management, 26(10), 1360-1381.

*Zikic, J., Bonache, J., \& Cerdin, J. (2010). Crossing national boundaries: A typology of qualified immigrants' career orientations. Journal of Organizational Behavior, 31(5), 667-686. doi:10.1002/job.705

Zikic, J., Bonache, J., \& Cerdin, J. L. (2010). Crossing national boundaries: A typology of qualified immigrants' career orientations. Journal of Organizational Behavior, 31(5), 667-686. 
Table 1. Journals and Disciplines

\begin{tabular}{|c|c|}
\hline Journal (No. of Articles) & $\begin{array}{l}\text { Discipline } \\
\text { Total Articles }\end{array}$ \\
\hline $\begin{array}{l}\text { Asian and Pacific Migration Journal (5), International Migration (5), } \\
\text { Journal of Ethnic and Migration Studies (3), Population Research and } \\
\text { Policy Review (2), Demographic Research (1), Demography (1) }\end{array}$ & $\begin{array}{l}\text { Demography } \\
17\end{array}$ \\
\hline $\begin{array}{l}\text { International Journal of Human Resource Management (5), Research } \\
\text { Policy (2), Journal of nursing management (1), Journal of Human } \\
\text { Resources (1), Human Resource Management Journal (1), Journal of } \\
\text { International Business Studies (1), Asia Pacific Journal of Human } \\
\text { Resources (1), Cross Cultural Management-an International Journal } \\
\text { (1), Career Development International (1), Journal of Organizational } \\
\text { Behavior (1), Organization (1), Journal of Technology Transfer (1) }\end{array}$ & $\begin{array}{l}\text { Management } \\
17\end{array}$ \\
\hline $\begin{array}{l}\text { American Economic Journal-Economic Policy (1), Applied } \\
\text { Economics Letters (1), Contemporary Economic Policy (1), Economia } \\
\text { Politica (1), Economic and Labour Relations Review (1), Economic } \\
\text { Geography (1), Economic inquiry (1), Economics of Education } \\
\text { Review (1), Feminist Economics (1), Journal of Business Economics } \\
\text { and Management (1), Journal of Development Economics (1), Journal } \\
\text { of Labor Economics (1), Journal of Population Economics (1), Labour } \\
\text { Economics (1), Public Choice (1), Review of Development Economics } \\
\text { (1) }\end{array}$ & $\begin{array}{l}\text { Economics } \\
16\end{array}$ \\
\hline $\begin{array}{l}\text { Population Space and Place (3), Geoforum (2), Antipode (1), Canadian } \\
\text { Geographer-Geographe Canadien (1), Environment and Planning A } \\
\text { (1), Erdkunde (1), Journal of Regional Science (1), Norsk Geografisk } \\
\text { Tidsskrift-Norwegian Journal of Geography (1), Regional Studies (1), } \\
\text { Social \& Cultural Geography (1), Tijdschrift Voor Economische En } \\
\text { Sociale Geografie (1) }\end{array}$ & $\begin{array}{l}\text { Geography } \\
14\end{array}$ \\
\hline $\begin{array}{l}\text { European Sociological Review (1), Global Networks-a Journal of } \\
\text { Transnational Affairs (1), Health Sociology Review (1), International } \\
\text { Journal of Intercultural Relations (1), International Sociology (1), } \\
\text { Journal of Contemporary Ethnography (1), Polish Sociological Review } \\
\text { (1), Sociological Quarterly (1), Sociological Review (1), Work } \\
\text { Employment and Society (1) }\end{array}$ & $\begin{array}{l}\text { Sociology } \\
10\end{array}$ \\
\hline $\begin{array}{l}\text { European journal of public health (1), Global Health Action (1), } \\
\text { Globalization and Health (1), Australian and New Zealand Journal of } \\
\text { Public Health (1), Rural and Remote Health (1), Social science \& } \\
\text { medicine (1), Journal of Rural Health (1), Ethnicity \& health (1), } \\
\text { Australian Journal of Rural Health (1) }\end{array}$ & $\begin{array}{l}\text { Public environmental } \\
\text { occupational health } \\
9\end{array}$ \\
\hline $\begin{array}{l}\text { American Behavioral Scientist (2), Applied Psychology-an } \\
\text { International Review-Psychologie Appliquee-Revue Internationale (1), } \\
\text { European Review of Applied Psychology-Revue Europeenne De } \\
\text { Psychologie Appliquee (1), Journal of Multicultural Counseling and } \\
\text { Development (1), Journal of vocational behavior (1), Personnel } \\
\text { Review (1) }\end{array}$ & $\begin{array}{l}\text { Psychology and applied } \\
\text { psychology } \\
7\end{array}$ \\
\hline $\begin{array}{l}\text { Human Resources for Health (4), Relations Industrielles-Industrial } \\
\text { Relations (1), Economic and Labour Relations Review (1), Employee } \\
\text { Relations (1) }\end{array}$ & $\begin{array}{l}\text { Industrial labor relations } \\
7\end{array}$ \\
\hline $\begin{array}{l}\text { Higher Education (2), Critical Studies in Education (1), Research in } \\
\text { Higher Education (1), Studies in Continuing Education (1), Teaching } \\
\text { and Teacher Education (1) }\end{array}$ & $\begin{array}{l}\text { Educational Research } \\
6\end{array}$ \\
\hline $\begin{array}{l}\text { Canadian Public Policy-Analyse De Politiques (1), Review of Public } \\
\text { Personnel Administration (1), Journal of European Social Policy (1) }\end{array}$ & $\begin{array}{l}\text { Public administration } \\
3\end{array}$ \\
\hline
\end{tabular}


Fingure 1. Conceptual Model of Skilled Migrants' Qualification-Matched Employment in the Host Country

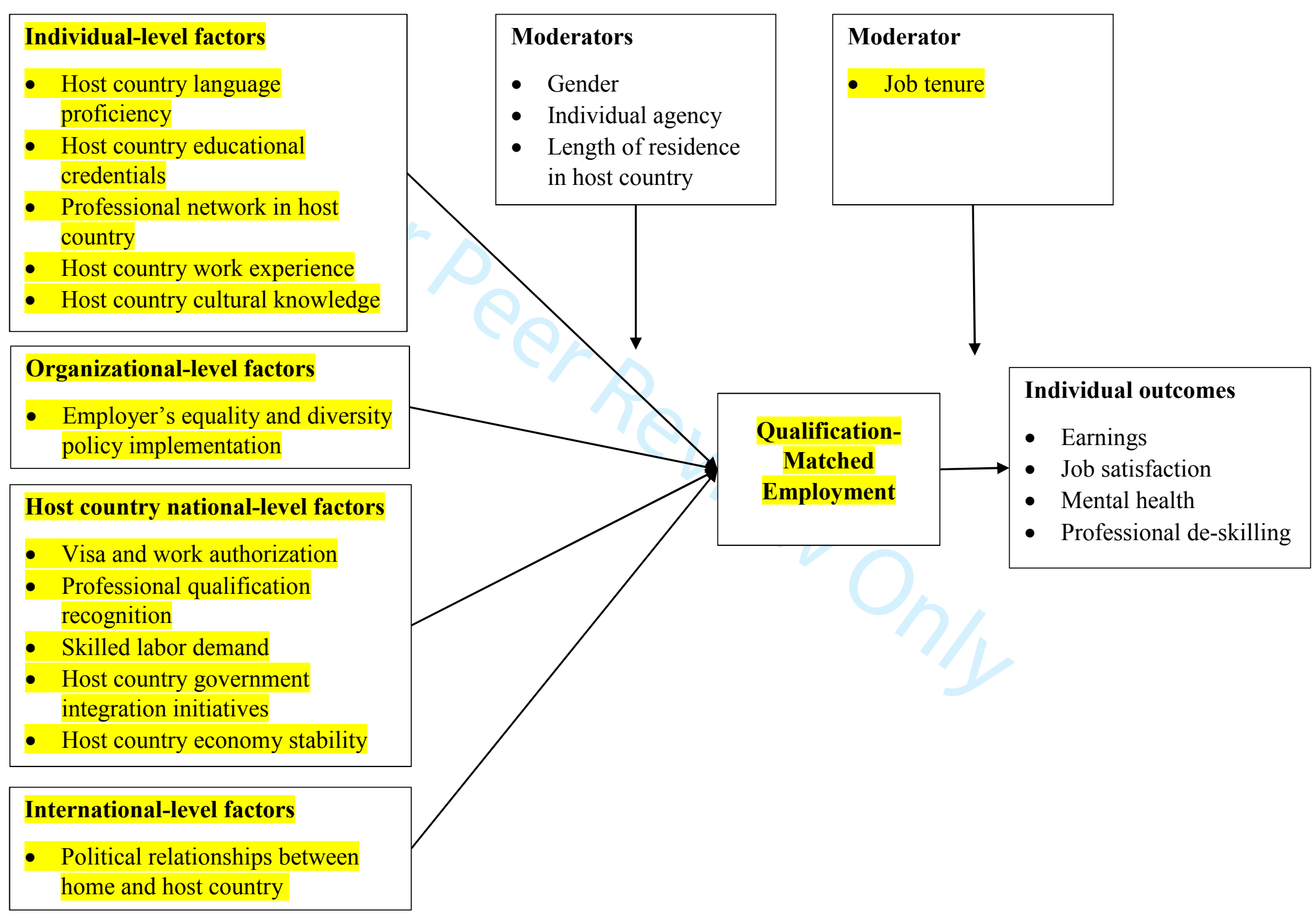


Thank you for the opportunity to revise and resubmit our review entitled "Understanding Skilled Migrants' Qualification-Matched Employment in the Host Country: A Multidisciplinary Review and a Conceptual Model” to the International Journal Human Resource Management.

We have highlighted the changes to our manuscript within the document using colored text. In the table below, we have responded to the reviewers' comments point-by-point.

Once again, thank you for the helpful and constructive feedback, and we look forward to hearing from you.

\section{Response to Reviewer 1's comments}

\begin{tabular}{|c|c|}
\hline Comment & Response \\
\hline $\begin{array}{l}\text { I like this study overall and find it is } \\
\text { well-written. The aims are clearly } \\
\text { stated, and the contribution is clearly } \\
\text { stated and evident in parts (but not } \\
\text { everywhere). Overall, this is a job } \\
\text { well done for the most part, but some } \\
\text { work is still needed. } \\
\text { I have some concerns that you need } \\
\text { to address: }\end{array}$ & $\begin{array}{l}\text { We appreciate this observation. } \\
\text { As suggested we revisited the findings section and re- } \\
\text { wrote this section to reflect our contributions. The } \\
\text { revised findings section uses a language that fits a } \\
\text { review article and no longer reads like an actual } \\
\text { study. We believe the revised findings section has } \\
\text { significantly improved (Please see highlighted text } \\
\text { pages 8-18 and Figure } 1 \text { on page } 41 \text { ). }\end{array}$ \\
\hline $\begin{array}{l}\text { 1. You do very well up until the } \\
\text { findings section of the manuscript; } \\
\text { easy to read and follow, clearly } \\
\text { outlined logic, sensible arguments, } \\
\text { well referenced and so on. I } \\
\text { wondered up until the middle part of } \\
\text { the paper whether I would be able to } \\
\text { make any recommendations for } \\
\text { improvement (!). }\end{array}$ & $\begin{array}{l}\text { Our review is now re-focused on skilled migrants' } \\
\text { qualification-matched employment. The new focus on } \\
\text { qualification-matched employment is now reflected } \\
\text { throughout the manuscript. We have made minor } \\
\text { changes to the title, abstract, introduction, methods, } \\
\text { and implications sections to show the focus on } \\
\text { qualification-matched employment (please see the } \\
\text { highlighted text in title, abstract, introduction, } \\
\text { methods, implications). }\end{array}$ \\
\hline $\begin{array}{l}\text { 2. But then, when one gets to } \\
\text { findings, here I struggled. The } \\
\text { findings are written in a manner to } \\
\text { suggest they are findings from an } \\
\text { actual study. The reference to this } \\
\text { and that study as 'finding' and } \\
\text { confirming various aspects of } \\
\text { migrants' lives is disconcerting; it } \\
\text { has been written as 'fact' ('so and so } \\
\text { found this') whereas it is only one } \\
\text { study that is referenced. I wonder, } \\
\text { then, if this is really a review, or } \\
\text { something else? It reads almost like a } \\
\text { book chapter - a synthesis/list of } \\
\text { prior studies rather than the } \\
\text { overarching review and critique the }\end{array}$ & $\begin{array}{l}\text { The revised findings section also presents the } \\
\text { contributions of our review more clearly (Figure } 1 \text { on } \\
\text { page } 41 \text { ). }\end{array}$ \\
\hline
\end{tabular}




\begin{tabular}{|c|c|}
\hline $\begin{array}{l}\text { introduction claims it to be. What I } \\
\text { mean is that a literature review is one } \\
\text { thing; a proper review is another. On } \\
\text { this, the paper failed to deliver (for } \\
\text { me at least) on its most important } \\
\text { promise and aims. Don't get me } \\
\text { wrong - it's interesting - but it's not } \\
\text { as sophisticated as I had hoped. } \\
\text { There was no WOW moment where } \\
\text { I learned something new. }\end{array}$ & \\
\hline $\begin{array}{l}\text { 3. On that, I would say 'contribution' } \\
\text { is lacking. You need to beef this up } \\
\text { by showing how many studies } \\
\text { found } \mathbf{x}, \mathbf{y} \text { and } \mathbf{z} \text {, as opposed to a } \\
\text { disparate (and long) list of 'factors' } \\
\text { that were each found by x, and then } \\
\text { more factors by y, and the more } \\
\text { factors by z. }\end{array}$ & $\begin{array}{l}\text { As recommended, we revised the findings section and } \\
\text { rewrote it in such a way that it indicates patterns } \\
\text { across the studies reviewed. } \\
\text { The revised findings section also reports how many } \\
\text { studies contributed to each factor identified in our } \\
\text { review. }\end{array}$ \\
\hline The question arises - so what? & $\begin{array}{l}\text { We revisited our analysis of the concept of } \\
\text { employment within the extant literature. In the } \\
\text { revised manuscript, we use the concept qualification- } \\
\text { matched employment as an overarching concept that } \\
\text { integrates the literature. } \\
\text { Our review is now re-focused on qualification- } \\
\text { matched employment. We have reflected the new } \\
\text { focus on qualification-matched employment } \\
\text { throughout the manuscript (see the highlighted text in } \\
\text { title, abstract, introduction, methods, and implications } \\
\text { sections). }\end{array}$ \\
\hline $\begin{array}{l}\text { 4. I like Table } 1 \text { and Figure } 1 \text {. But I } \\
\text { find even this information to be } \\
\text { fairly 'simple'. What is the } \\
\text { contribution? }\end{array}$ & $\begin{array}{l}\text { We have rewritten the discussion section to reflect } \\
\text { our contributions more clearly (please see pages } 18 \text { - } \\
21 \text { ). }\end{array}$ \\
\hline
\end{tabular}

